\title{
Singulisphaera acidiphila gen. nov., sp. nov., a non-filamentous, Isosphaera-like planctomycete from acidic northern wetlands
}

\begin{abstract}
Correspondence
Svetlana N. Dedysh dedysh@mail.ru
\end{abstract}

\author{
Irina S. Kulichevskaya, ${ }^{1}$ Anastasia O. Ivanova, ${ }^{1}$ Olga I. Baulina, ${ }^{2}$ \\ Paul L. E. Bodelier, ${ }^{3}$ Jaap S. Sinninghe Damsté ${ }^{4}$ and Svetlana N. Dedysh ${ }^{1}$ \\ ${ }^{1}$ S. N. Winogradsky Institute of Microbiology, Russian Academy of Sciences, Prospect 60-letya \\ Octyabrya 7/2, Moscow 117312, Russia
${ }^{2}$ M. V. Lomonosov Moscow State University, Faculty of Biology Science, GSP-2, Leninskie Gory, Moscow 119992, Russia \\ ${ }^{3}$ Netherlands Institute of Ecology, NL-3631 AC Nieuwersluis, The Netherlands \\ ${ }^{4}$ Royal Netherlands Institute for Sea Research, Department of Marine Biogeochemistry and \\ Toxicology, PO Box 59, 1790 AB Den Burg, The Netherlands
}

\begin{abstract}
Four novel strains of budding bacteria, designated MOB10 ${ }^{\top}, \mathrm{PO} 2, \mathrm{MPL} 1015$ and BG32, were isolated from acidic wetlands of northern Russia. Cells of these four strains were aerobic, non-motile spheres that occurred singly or in shapeless aggregates and attached to surfaces by means of a holdfast material. The isolates were moderately acidophilic, mesophilic organisms capable of growth between $\mathrm{pH} 4.2$ and 7.5 (optimum growth at $\mathrm{pH} 5.0-6.2$ ) and at temperatures between 4 and $33{ }^{\circ} \mathrm{C}$ (optimum growth at 20-26 ${ }^{\circ} \mathrm{C}$ ). The strains possessed a complex intracellular membrane system that compartmentalized the cells. The major fatty acids were $\mathrm{C}_{16: 0}$, $\mathrm{C}_{18: 1} \omega 9 c$ and $\mathrm{C}_{18: 2} \omega 6 c, 12 c$. The major quinone was menaquinone- 6 (MK-6). The $\mathrm{G}+\mathrm{C}$ content of the DNA was 57.8-59.9 mol\%. 16S rRNA gene sequence analysis showed that strains $\mathrm{MOB} 10^{\top}, \mathrm{PO} 2, \mathrm{MPL} 1015$ and $\mathrm{BG} 32$ were members of the order Planctomycetales and belonged to a phylogenetic lineage defined by the genus Isosphaera, exhibiting $90 \%$ sequence similarity to the type strain of the thermophilic planctomycete /sosphaera pallida and 95-95.5\% sequence similarity to a taxonomically uncharacterized group of filamentous bacteria from activated sludge, 'Nostocoida limicola' III. However, compared with 'Nostocoida limicola' III and Isosphaera pallida, the new isolates from acidic wetlands were non-filamentous, unpigmented bacteria, which possessed highly distinctive phospholipid fatty acid profiles and were capable of growth and of degrading several biopolymers under acidic, microaerobic and cold conditions. The data suggest that the four isolates should be considered as representing a novel species of a new genus of the order Planctomycetales, for which the name Singulisphaera acidiphila gen. nov., sp. nov. is proposed. The type strain of Singulisphaera acidiphila is

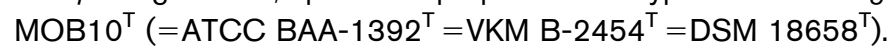

Members of the order Planctomycetales are ubiquitous in a wide range of terrestrial and aquatic environments with diverse conditions (Staley et al., 1992; Schlesner, 1994; Fuerst, 1995, 2004; Ward et al., 2006). We recently showed

Abbreviations: FISH, fluorescence in situ hybridization; PLFA, phospholipid fatty acid.

The GenBank/EMBL/DDBJ accession numbers for the 16S rRNA gene sequences of strains MOB10 ${ }^{\top}, \mathrm{MPL} 1015, \mathrm{PO} 2$ and BG32 are AM850678, AM902525, AM902526 and AM902527, respectively.

A graph showing the influence of medium $\mathrm{pH}$ on growth of strain MOB $10^{\top}$ is available as supplementary material with the online version of this paper. that these micro-organisms are highly abundant in acidic Sphagnum-dominated northern wetlands (Dedysh et al., 2006; Kulichevskaya et al., 2006; Ivanova \& Dedysh, 2006). Bacterial cells revealed in Sphagnum peat by means of fluorescence in situ hybridization (FISH) with two phylumspecific 16S rRNA-targeted oligonucleotide probes for planctomycetes, PLA46 and PLA886 (Neef et al., 1998), had ellipsoid or spherical morphology. By using an effective combination of a traditional isolation technique with FISH-based monitoring of the enrichment procedure, we succeeded in isolating several peat-inhabiting, acidophilic planctomycetes in pure culture (Dedysh et al., 2006; Kulichevskaya et al., 2006). Three of these isolates were 
ellipsoid-shaped and rosette-forming bacteria, which belonged to a phylogenetic lineage defined by the genus Planctomyces. They were recently described as representing a novel species of a new genus, Schlesneria paludicola (Kulichevskaya et al., 2007). Another morphologically distinct group of isolates from acidic peat was represented by large, non-motile, spherical cells that occurred singly, in pairs or in shapeless aggregates. Similar cell morphology was previously reported for a few Isosphaera-like planctomycetes isolated from diverse sources, i.e. from leakage water of a compost heap, a pitcher of Nepenthes sp. and a laboratory ampicillin solution (Schlesner, 1994; Ward et al., 1995, Wang et al., 2002). None of these strains has been described taxonomically. Thus, the goal of the present study was to characterize the newly isolated planctomycete strains from acidic wetlands and to determine their taxonomic position.

Strain $\mathrm{MOB} 10^{\mathrm{T}}$ was obtained from acidic peat $(\mathrm{pH} 4.2)$ collected from the upper $(0-10 \mathrm{~cm})$ oxic layer of the bog Obukhovskoe, in the Yaroslavl region of northern

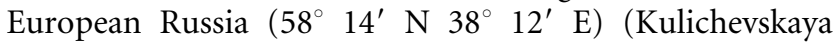
et al., 2006). Two further strains, PO2 and MPL1015, were isolated from a peat soil ( $\mathrm{pH}$ 4.0) sampled at a depth of $10-20 \mathrm{~cm}$ (with a water table at approximately $15 \mathrm{~cm}$ depth) of the Sphagnum peat bog Bakchar, Tomsk region, western Siberia $\left(56^{\circ} 51^{\prime} \mathrm{N} 82^{\circ} 50^{\prime} \mathrm{E}\right)$. A fourth strain, BG32, was obtained from a peat sample $(\mathrm{pH} 4.2)$ collected from the upper $(0-10 \mathrm{~cm})$ layer of an unnamed ombrotrophic (rainwater-dependent) bog located within the catchment area of the acidic humic lake Dubrovskoe, Darwin State Preserve, Vologda region, northern European Russia $\left(58^{\circ} 30^{\prime} \mathrm{N} 37^{\circ} 80^{\prime} \mathrm{E}\right)$. The isolation procedure and culture conditions used were as described by Dedysh et al. (2006) and Kulichevskaya et al. (2006). The isolates were maintained on agar medium M31 (modification of medium 31 described by Staley et al., 1992) containing (per litre distilled water): $0.1 \mathrm{~g} \mathrm{KH}_{2} \mathrm{PO}_{4}, 20 \mathrm{ml}$ Hutner's basal salts, $1.0 \mathrm{~g} N$-acetylglucosamine, $0.2 \mathrm{~g}$ ampicillin (sodium salt), $0.1 \mathrm{~g}$ peptone, $0.1 \mathrm{~g}$ yeast extract and $15 \mathrm{~g}$ agar-agar (Difco), pH 5.8.

Morphological observations and cell size measurements were made with a Zeiss Axioplan 2 microscope and Axiovision 4.2 software (Zeiss). For the preparation of ultrathin sections, cells from 10-day-old agar cultures were fixed in $2 \%(\mathrm{w} / \mathrm{v})$ glutaraldehyde in $0.1 \mathrm{M}$ sodium cacodylate buffer $(\mathrm{pH} 6.8)$ for $0.5 \mathrm{~h}$ and then post-fixed in $1 \%(\mathrm{w} / \mathrm{v})$ osmium tetroxide in the same buffer for $4 \mathrm{~h}$, dehydrated through a graded ethanol series and embedded in araldite. Thin sections were cut on an LKB-8800 ultramicrotome, stained with lead citrate (Reynolds, 1963) and examined with a transmission electron microscope (JEM-1011; JEOL). For scanning electron microscopy, bacteria were fixed in $2 \%(\mathrm{w} / \mathrm{v})$ glutaraldehyde in liquid medium M31 without carbon sources for $0.5-1 \mathrm{~h}$ and in some cases post-fixed in $1 \%(\mathrm{w} / \mathrm{v})$ osmium tetroxide in the same medium for $4 \mathrm{~h}$. The samples were then dehydrated through an ethanol series, left in absolute acetone overnight, critical-point dried (Dryer HCP-2), coated with Au-Pd alloy (IB-3 Ion Coater) and examined with a JEOL JSM-6380LA scanning electron microscope.

Physiological tests were performed in batch cultures grown in liquid medium M31 (in $100 \mathrm{ml}$ flasks containing $20 \mathrm{ml}$ medium). Growth of strains MOB10 ${ }^{\mathrm{T}}$, MPL1015, PO2 and BG32 was monitored by nephelometry at $600 \mathrm{~nm}$ in an Eppendorf BioPhotometer for 7-14 days under a variety of conditions, including temperatures of $4-37{ }^{\circ} \mathrm{C}, \mathrm{pH} 3.8-8.0$ and $\mathrm{NaCl}$ concentrations of $0-3.0 \%(\mathrm{w} / \mathrm{v})$. Except for temperature experiments, the flasks were incubated on a rotary shaker at 120 r.p.m. and at $24{ }^{\circ} \mathrm{C}$. Variations in $\mathrm{pH}$ were achieved by mixing $0.1 \mathrm{M}$ solutions of $\mathrm{H}_{2} \mathrm{SO}_{4}$ and $\mathrm{KOH}$. At intervals of 1-2 days, the flasks were examined for cell growth by measuring the $\mathrm{OD}_{600}$ and $\mathrm{pH}$ of the culture liquid. The specific growth rate calculated for each incubation period was correlated with the mean $\mathrm{pH}$ observed for a particular flask at the beginning and at the end of the incubation period. Carbon source utilization was determined by using liquid mineral medium (MM) supplemented with the respective carbon source $(0.05 \%$, $\mathrm{w} / \mathrm{v}$ ). $\mathrm{MM}$ contained (per litre distilled water): $0.1 \mathrm{~g}$ $\mathrm{KH}_{2} \mathrm{PO}_{4}, 0.1 \mathrm{~g}\left(\mathrm{NH}_{4}\right)_{2} \mathrm{SO}_{4}, 0.1 \mathrm{~g} \mathrm{MgSO} 4.7 \mathrm{H}_{2} \mathrm{O}$ and $1 \mathrm{ml}$ of metal salt solution '44' (Staley et al., 1992), with $\mathrm{pH}$ adjusted to 5.5. Cultivation was done in $100-\mathrm{ml}$ flasks containing $10 \mathrm{ml}$ medium. Cultures were incubated at $25{ }^{\circ} \mathrm{C}$ for $2-3$ weeks on a shaker. The ability of the strains to degrade different biopolymers was examined by measuring the rate of $\mathrm{CO}_{2}$ production in tightly closed $120-\mathrm{ml}$ serum bottles containing $10 \mathrm{ml}$ liquid MM with $0.05 \%(\mathrm{w} / \mathrm{v})$ of the corresponding polymer substrate for 1 month at $20{ }^{\circ} \mathrm{C}$. Control incubations were run in parallel under the same conditions but without substrate. Oxidative and fermentative utilization of carbohydrates was determined as described for the Hugh-Leifson test (Gerhardt, 1981) and by using an API 20 NE kit (bioMérieux). Enzyme activities were examined by using an API ZYM kit (bioMérieux). Nitrogen source utilization was tested by using liquid MM with $0.05 \%$ glucose in which $\left(\mathrm{NH}_{4}\right)_{2} \mathrm{SO}_{4}$ was replaced with one of the following compounds at a concentration of $0.05 \%(\mathrm{w} / \mathrm{v}): \mathrm{KNO}_{3}$, $\mathrm{KNO}_{2}$, urea or one of the amino acids listed in Table 1. Cultures were tested for growth under anaerobic conditions in jars by using AnaeroGen anaerobic system envelopes (Oxoid). Susceptibility to antibiotics was determined on M31 agar plates by using discs containing the following: ampicillin $(10 \mu \mathrm{g})$, gentamicin $(10 \mu \mathrm{g})$, kanamycin $(30 \mu \mathrm{g})$, neomycin $(10 \mu \mathrm{g})$, novobiocin $(30 \mu \mathrm{g})$, streptomycin $(10 \mu \mathrm{g})$, chloramphenicol $(30 \mu \mathrm{g})$ and lincomycin $(10 \mu \mathrm{g})$ (Oxoid).

For fatty acid, neutral lipid and quinone analyses, cells of the new isolates were grown on liquid medium M31 and then harvested at the late-exponential growth phase. Phospholipid fatty acid (PLFA) and isoprenoid quinone analyses were performed as described for Schlesneria paludicola (Kulichevskaya et al., 2007). For neutral lipid analysis, the procedures described by Sinninghe Damsté 
Table 1. Phenotypic characteristics of strains $M O B 10^{\top}$, MPL1015, PO2 and BG32

None of the strains showed pigmentation, and all strains grew at 4$33{ }^{\circ} \mathrm{C}$. All strains utilized glucose, fructose, galactose, lactose, cellobiose, maltose, mannose, melibiose, rhamnose, ribose, trehalose, sucrose, xylose, $\mathrm{N}$-acetylglucosamine and salicin. All strains were capable of hydrolysing laminarin, pectin, chondroitin sulfate, aesculin, pullulan, lichenan and xylan and were able to liquefy gelatin. None of the strains utilized raffinose, sorbose, glycerol, methanol, ethanol, starch, glucuronic acid, benzoate, caproate, citrate, formate, formaldehyde, fumarate, glutarate, malate, succinate, propionate, mannitol, tartrate, alanine, arginine, asparagine, aspartate, cysteine, cystine, glutamine, glycine, histidine, isoleucine, leucine, lysine, methionine, norleucine, ornithine, phenylalanine, proline, serine, threonine, tryptophan, tyrosine or valine. None of the strains was capable of hydrolysing starch or chitin. All strains utilized ammonia, alanine, aspartate, glutamine, threonine, arginine, tryptophan and glycine as nitrogen sources. None of the strains utilized nitrate, nitrite, urea, cysteine, cystine, histidine, leucine, methionine, norleucine, ornithine, serine or tyrosine as nitrogen sources. ND, Not determined.

\begin{tabular}{|lcccc|}
\hline Characteristic & MOB10 & MPL1015 & PO2 & BG32 \\
\hline Cell diameter $(\mu \mathrm{m})$ & $1.6-2.5$ & $1.8-2.3$ & $1.8-2.6$ & $1.7-2.5$ \\
Salinity tolerance $(\% \mathrm{NaCl})$ & $<0.4$ & $<0.3$ & $<0.2$ & $<0.5$ \\
$\mathrm{pH}$ growth range & $4.2-7.2$ & $4.2-7.5$ & $4.2-7.5$ & $4.2-7.5$ \\
$\mathrm{pH}$ optimum & $5.1-6.2$ & $5.0-6.2$ & $5.0-6.1$ & $5.0-6.2$ \\
Temperature optimum $\left({ }^{\circ} \mathrm{C}\right)$ & $20-28$ & $18-26$ & $15-26$ & $15-26$ \\
Carbon source utilization & & & & \\
Fucose & - & + & + & + \\
Leucrose & + & + & - & + \\
Acetate & - & - & - & + \\
Lactate & + & - & - & + \\
Pyruvate & + & - & - & + \\
Nitrogen source utilization & & & & \\
Asparagine & + & + & - & - \\
Isoleucine & + & - & - & - \\
Lysine & - & - & - & + \\
Phenylalanine & - & - & - & + \\
Proline & + & - & + & - \\
Valine & - & - & - & + \\
DNA G+C content $(\mathrm{mol} \%)$ & 59.9 & 59.4 & 57.8 & $\mathrm{ND}$ \\
& & & & \\
\hline
\end{tabular}

et al. (2004) were used. Genomic DNA from the novel strains was extracted as described by Marmur (1961). The $\mathrm{G}+\mathrm{C}$ content of the DNA was determined by means of thermal denaturation by using a Unicam SP1800 spectrophotometer at a heating rate of $0.5{ }^{\circ} \mathrm{C} \mathrm{min}{ }^{-1}$ and was calculated according to Owen et al. (1969). PCR-mediated amplification of the 16S rRNA gene from positions 28 to 1491 (numbering according to the International Union of Biochemistry nomenclature for the Escherichia coli $16 \mathrm{~S}$ rRNA gene) was performed by using primers $9 \mathrm{f}$ and $1492 \mathrm{r}$ and the reaction conditions described by Weisburg et al. (1991). The 16S rRNA gene amplicons were purified by using QIAquick spin columns (Qiagen) and were sequenced on an ABI Prism 377 DNA sequencer with BigDye terminator chemistry, as specified by the manufacturer
(PE Applied Biosystems). Phylogenetic analysis was carried out by using the ARB program package (Ludwig et al., 2004). The newly obtained $16 \mathrm{~S}$ rRNA gene sequences were added to the ARB database SSU_04 and were aligned manually. Trees were constructed by using distance-based (neighbour-joining), maximum-likelihood (DNAML) and maximum-parsimony methods. Significance levels of interior branch points obtained in the neighbour-joining analysis were determined by bootstrap analysis (1000 data resamplings) via PHYLIP (Felsenstein, 1989).

On agar medium M31, the isolates from Sphagnum peat formed raised, opaque, colourless, circular colonies with an entire edge and a smooth surface. At an early stage of isolation, 1-month-old colonies of these bacteria did not exceed $1 \mathrm{~mm}$ in diameter; after a series of further transfers on laboratory media at $24{ }^{\circ} \mathrm{C}$, the isolates began to form significantly larger colonies, $2-4 \mathrm{~mm}$ in diameter. No gliding motility was observed in cultures of the new isolates. Mature cells of strains MOB10 ${ }^{\mathrm{T}}$, MPL1015, PO2 and BG32 were spherical and typically varied in size from 1.6 to $2.6 \mu \mathrm{m}$, although some cells in old cultures were up to $3 \mu \mathrm{m}$ in diameter (Fig. 1a, b). Cells were non-motile and encapsulated. They reproduced by budding and occurred singly, in pairs or were arranged in shapeless aggregates. No stable cell chains or filaments were observed in cultures of the novel strains. Examination of old cultures grown on agar plates revealed the presence of an amorphous holdfast substance excreted from the poles of many cells (Fig. 1b). Similar holdfast production, which enables the cells to attach to surfaces or to form aggregates by attaching to each other, has been reported for Pirellula-like bacteria (Schlesner, 1994).

Thin-sectioned cells of strain $\mathrm{MOB} 10^{\mathrm{T}}$ displayed the pattern of compartmentalization typical for Isosphaera-like planctomycetes (Fig. 1c) (Giovannoni et al., 1987a, b; Lindsay et al., 2001; Liu et al., 2001; Wang et al., 2002; Fuerst, 2005; Ward et al., 2006). Two electron-dense layers separated by an electron-transparent layer were clearly visible in the ultrastructure of the cell wall. These may correspond to a thin glycocalyx-like layer, an outer membrane and the underlying proteinaceous layer. Total wall thickness was about $12 \mathrm{~nm}$. Pit-like structures with a diameter of $25 \mathrm{~nm}$ were distributed uniformly over the cell surface. An enlarged view of the cross-section of one of these pit-like structures showed that it represents a cell-wall invagination, which is connected to underlying paryphoplasm (Fig. 1d). The intracytoplasmic membrane compartmentalized the cell to produce irregularly shaped membrane-bound regions ramifying throughout the cytoplasm. The paryphoplasm in cells of strain $\mathrm{MOB} 10^{\mathrm{T}}$ was invaginated such that this resulted in a large central region and numerous peripheral regions. These regions were filled with an electron-dense substance. Multiple nucleoid zones, possibly from a single folded nucleoid being sectioned more than once, and electron-dense ribosome-like particles were observed in the central part of the cell. Many ribosome-like particles were aligned regularly against the 

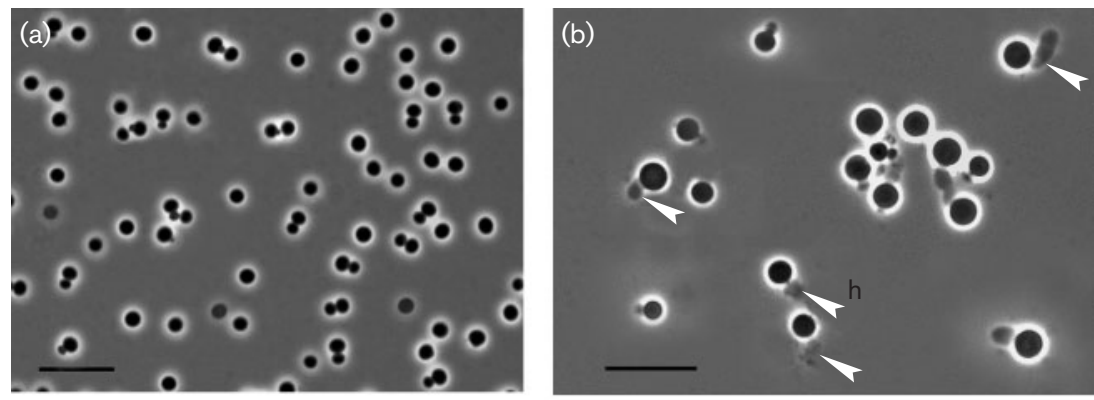

(c)

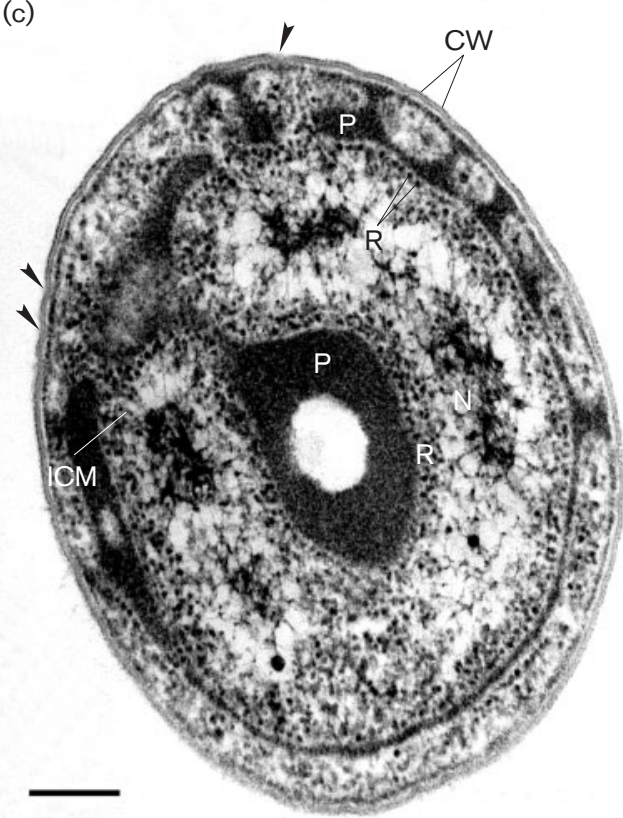

(d)
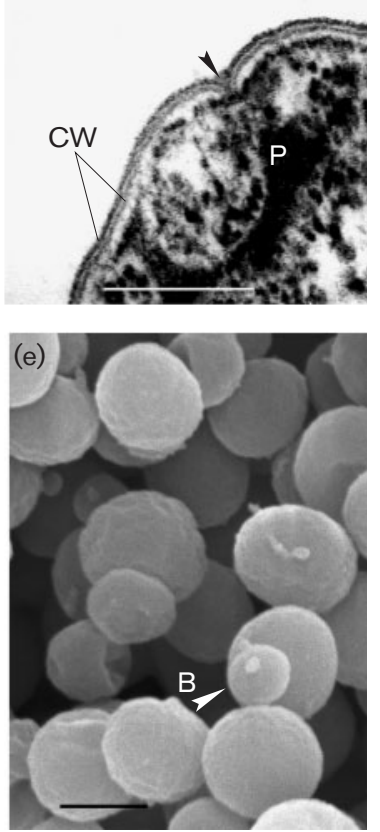

Fig. 1. Phase-contrast micrographs of cells of strain $\mathrm{MOB} 10^{\top}$ grown for 10 days in liquid culture (a) and of cells of strain MPL1015 grown for 1 month on agar medium (b). White arrowheads in (b) indicate amorphous holdfast substance excreted by the cells. Bars, $10 \mu \mathrm{m}$. (c) Electron micrograph of an ultrathin section of a cell of strain MOB10 ${ }^{\top}$. CW, Cell wall; ICM, intracytoplasmic membrane; $P$, paryphoplasm; R, ribosome-like particles; $\mathrm{N}$, nucleoid. Black arrowheads indicate pit-like invaginations of the cell wall [enlarged view in (d)]. Bar, $0.2 \mu \mathrm{m}$. (e) Scanning electron micrograph of cells of strain $\mathrm{MOB} 10^{\top}$ grown on agar medium M31. B, Bud. Bar, $1 \mu \mathrm{m}$. intracytoplasmic membrane. Apart from the large central ribosome-containing region, the cells also possessed numerous peripheral electron-transparent areas with scattered ribosomes. Scanning electron microscopy did not reveal any additional structures on the cell surface of the novel strains (Fig. 1e).

Strains MOB10 ${ }^{\mathrm{T}}, \mathrm{MPL} 1015, \mathrm{PO} 2$ and BG32 were obligately aerobic chemoheterotrophs. In contrast to other peatinhabiting planctomycetes of the genus Schlesneria, they were not capable of fermenting carbohydrates; however, they grew well under microaerobic conditions.

A list of carbon substrates tested in our experiments and the results of the tests are given in the species description below and in Table 1 . Most sugars and $N$-acetylglucosamine were the preferred growth substrates. Organic acids either were not utilized or were utilized poorly by some of the strains. All the new isolates were capable of hydrolysing laminarin, pectin, chondroitin sulfate, aesculin, gelatin, pullulan, lichenan and xylan, but not starch, chitin or cellulose. All the strains showed catalase, cytochrome oxidase and urease activities. Dissimilatory nitrate reduction was negative. Growth factors were not required.
Ammonia, $\mathrm{N}$-acetylglucosamine, Bacto peptone, Bacto yeast extract, alanine, aspartate, arginine, glutamine, threonine, tryptophan and glycine were utilized as nitrogen sources. Some of the novel strains were also able to utilize asparagine, isoleucine, lysine, phenylalanine, proline and valine. Nitrate and nitrite were not utilized. The following enzyme activities (API ZYM) were detected in all of the novel strains: alkaline and acid phosphatases, esterase, esterase lipase, leucine arylamidase, cystine arylamidase, valine arylamidase, phosphohydrolase, $N$-acetyl- $\beta$-glucosaminidase and $\beta$-galactosidase. The following enzyme activities were absent: arginine dihydrolase, lipase, trypsin, chymotrypsin, $\alpha$-galactosidase, $\beta$-glucuronidase, $\alpha$-glucosidase and $\alpha$-mannosidase. All the isolates were resistant to ampicillin, streptomycin, chloramphenicol, lincomycin, kanamycin and novobiocin, but sensitive to neomycin and gentamicin.

Strains $\mathrm{MOB}^{\mathrm{T}}{ }^{\mathrm{T}}$, MPL1015, PO2 and BG32 grew in the range $\mathrm{pH} 4.2-7.5$, with optimum growth at $\mathrm{pH}$ 5.0-6.2 (Table 1; see also Supplementary Fig. S1, available in IJSEM Online). The temperature range for growth was $4-33{ }^{\circ} \mathrm{C}$, with optimum growth at $20-26{ }^{\circ} \mathrm{C}$ (Table 1 ). The isolates 
from wetlands were highly sensitive to salt stress. Growth inhibition of $50-80 \%$ was observed in the presence of $\mathrm{NaCl}$ in the medium at concentrations of $0.2-0.5 \%(\mathrm{w} / \mathrm{v})$, and $\mathrm{NaCl}$ at concentrations above $0.5 \%(\mathrm{w} / \mathrm{v})$ completely inhibited growth.

Similar to other described planctomycetes (Sittig \& Schlesner, 1993; Ward et al., 2006; Kulichevskaya et al., 2007), the new isolates contained menaquinone-6 (MK-6) as the predominant isoprenoid quinone. The major components of the PLFA profiles of strains MOB10 ${ }^{\mathrm{T}}$, MPL1015, PO2 and BG32 were $\mathrm{C}_{16: 0}, \mathrm{C}_{18: 1} \omega 9 c$ and $\mathrm{C}_{18: 2} \omega 6 c, 12 c$ (Table 2). One of the strains, BG32, also contained a significant amount (about 22\%) of $\mathrm{C}_{18: 2} \omega 7 c, 12 c$. High levels of $\mathrm{C}_{16: 0}$ and $\mathrm{C}_{18: 1} \omega 9 c$ fatty acids are characteristic of members of the family Planctomycetaceae, i.e. the genera Planctomyces and Pirellula (Kerger et al., 1988). However, none of the taxonomically described planctomycetes, including Isosphaera pallida (Giovannoni et al., 1987b) or representatives of the recently described genus Schlesneria (Kulichevskaya et al., 2007), possess $\mathrm{C}_{18: 2}$ fatty acids. The PLFA profiles of the novel strains are thus distinct and suggest differentiation at the genus level. The neutral lipids of strains MOB10 ${ }^{\mathrm{T}}$, MPL1015 and PO2 were dominated by an $\mathrm{n}-\mathrm{C}_{31: 9}$ hydrocarbon previously detected in Antarctic bacteria (Nichols et al., 1995) as well as in Planctomyces limnophilus and Schlesneria species (Kulichevskaya et al., 2007) (Table 3). Squalene and, to a lesser extent, the hopanoids diplopterol and 3-methyl diplopterol were also detected. Upon base hydrolysis of the residue following extraction, in addition to $\mathrm{C}_{16}$ and $\mathrm{C}_{18}$ fatty acids, the

Table 2. Phospholipid fatty acid (PLFA) composition of the novel planctomycete strains from acidic peatlands

Values shown are percentages of total PLFAs. Major components are shown in bold. Components comprising $<0.1 \%$ of the total were not included.

\begin{tabular}{|lrrrr|}
\hline Fatty acid & MOB10 $^{\text {T }}$ & MPL1015 & PO2 & BG32 \\
\hline $\mathrm{C}_{14: 0}$ & 1.06 & 1.07 & 1.50 & 0.73 \\
$\mathrm{C}_{15: 0}$ & 0.23 & 0.75 & 0.26 & 0.61 \\
iso- $_{16: 0}$ & & 0.15 & 0.13 & 0.14 \\
$\mathrm{C}_{16: 0}$ & $\mathbf{3 1 . 1 2}$ & $\mathbf{3 4 . 1 2}$ & $\mathbf{3 6 . 5 9}$ & $\mathbf{2 3 . 8 9}$ \\
$\mathrm{C}_{16: 1} \omega 5 t$ & & & 0.13 & \\
$\mathrm{C}_{16: 1} \omega 9 c$ & & 0.13 & & \\
$\mathrm{C}_{16: 1} \omega 7 c$ & 1.65 & 1.66 & 1.41 & 1.40 \\
$\mathrm{C}_{17: 0}$ & 0.13 & 0.41 & 0.17 & 0.26 \\
cyclo $\mathrm{C}_{17: 0}$ & 0.43 & 0.86 & 0.35 & 0.89 \\
$\mathrm{C}_{18: 0}$ & 3.51 & 3.77 & 2.56 & 3.39 \\
$\mathrm{C}_{18: 1} \omega 11 t$ & 0.12 & 0.14 & & \\
$\mathrm{C}_{18: 1} \omega 9 t$ & & & & 0.58 \\
$\mathrm{C}_{18: 1} \omega 9 c$ & $\mathbf{4 6 . 7 3}$ & $\mathbf{4 0 . 8 4}$ & $\mathbf{3 0 . 5 8}$ & $\mathbf{2 3 . 4 8}$ \\
$\mathrm{C}_{18: 1} \omega 7 c$ & 0.79 & 0.81 & & 0.51 \\
$\mathrm{C}_{18: 2} \omega 7 c, 12 c$ & & & & $\mathbf{2 1 . 7 2}$ \\
$\mathrm{C}_{18: 2} \omega 6 c, 12 c$ & $\mathbf{1 3 . 7 9}$ & $\mathbf{1 5 . 1 9}$ & $\mathbf{2 5 . 5 8}$ & $\mathbf{2 1 . 8 9}$ \\
$\mathrm{C}_{20: 0}$ & 0.11 & 0.29 & 0.22 & 0.15 \\
\hline
\end{tabular}

Table 3. Major neutral lipids of strains $\mathrm{MOB}^{\top}{ }^{\top}$, MPL 1015 and $\mathrm{PO} 2$

Values shown are percentages of total neutral lipids quantified. Strain BG32 was not included in this analysis.

\begin{tabular}{|lccc|}
\hline Compound & MOB10 $^{\text {T }}$ & MPL1015 & PO2 \\
\hline Squalene & 28 & 40 & 18 \\
$n$-C $_{31: 9}$ & 68 & 54 & 79 \\
Diplopterol & 3 & 4 & 2 \\
3-Methyl diplopterol & 1 & 2 & 1 \\
\hline
\end{tabular}

uncommon 27-hydroxy-octacosanoic acid was released in considerable proportions in all the novel strains.

Comparative 16S rRNA gene sequence analysis showed that strains MOB10 ${ }^{\mathrm{T}}$, PO2, MPL1015 and BG32 were members of the order Planctomycetales and belonged to a phylogenetic lineage defined by the genus Isosphaera (Fig. 2). However, levels of sequence similarity between the type strain of the only taxonomically described member of this lineage, I. pallida - a thermophilic gliding bacterium from hot springs (Giovannoni et al., 1987a) - and the novel isolates from northern wetlands were quite low (about $90 \%$ ), suggesting their differentiation at the genus level. The four novel strains possessed nearly identical (99.8$99.9 \%$ similarity) $16 \mathrm{~S}$ rRNA gene sequences and were most closely related to the taxonomically uncharacterized Isosphaera-like isolate Schlesner 640 isolated from a compost leakage water (Ward et al., 1995) (95.5\% sequence similarity), Isosphaera-like strain C2-3 from a laboratory ampicillin solution (Wang et al., 2002) (95\% sequence identity) and a group of filamentous planctomycete strains from activated sludge, 'Nostocoida limicola' III (Liu et al., 2001) (94.5-95.5\% sequence identity). The DNA G + C content of the novel strains ranged from 57.8 to $59.9 \mathrm{~mol} \%$. The corresponding value reported for $I$. pallida $\mathrm{IS}_{\mathrm{B}} \mathrm{B}^{\mathrm{T}}$ is $62.2 \mathrm{~mol} \%$ (Giovannoni et al., 1987a).

Morphologically, the non-filamentous, unpigmented isolates from acidic wetlands were clearly distinct from both $I$. pallida and 'Nostocoida limicola' III. As no information except a detailed morphological characterization is available for strains of 'Nostocoida limicola' III, we compared the phenotypic and genotypic features of the novel strains with those of I. pallida (Table 4). In contrast to I. pallida, the new isolates were non-thermophilic bacteria capable of growth under microaerobic, acidic and cold conditions. They showed hydrolytic capabilities and possessed quite distinct PLFA profiles. We also failed to detect gliding motility and phototactic activity in the novel strains under the conditions described by Giovannoni et al. (1987a). Thus, based on significant morphological, phenotypic and genotypic differences between the newly isolated strains and I. pallida, we suggest that strains MOB10 ${ }^{\mathrm{T}}$, MPL1015, $\mathrm{PO} 2$ and BG32 represent a novel species of a new genus within the order Planctomycetales, for which the name Singulisphaera acidiphila gen. nov., sp. nov. is proposed. 


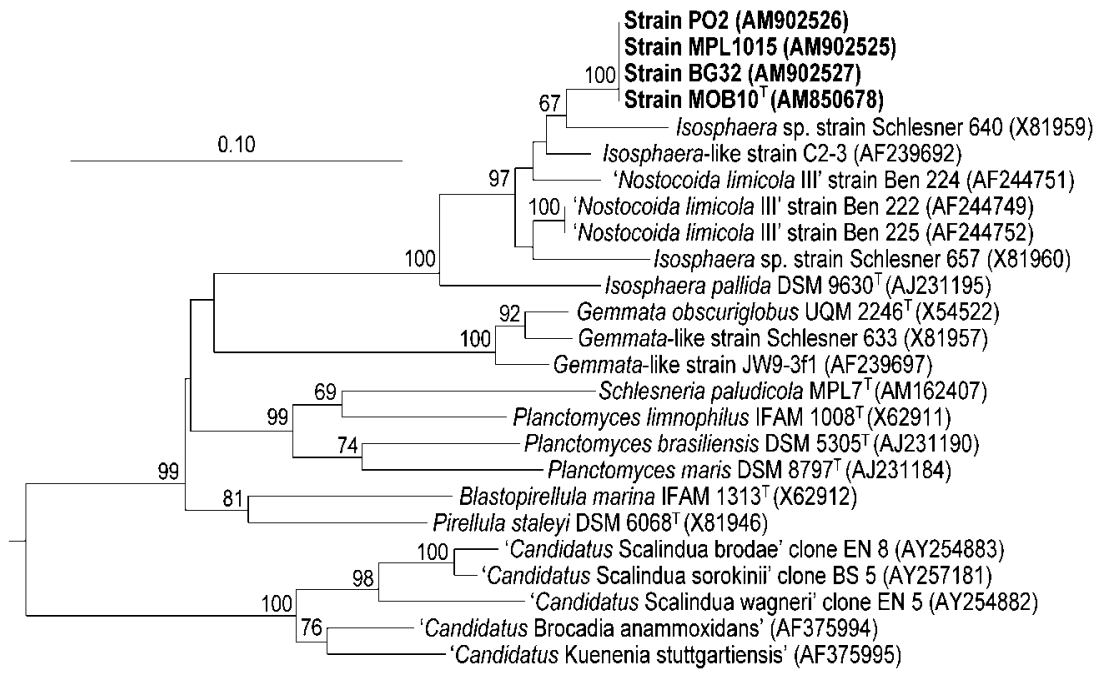

Fig. 2. Neighbour-joining tree (Jukes-Cantor correction) based on 16S rRNA gene sequences showing the phylogenetic position of strains MOB10', MPL1015, PO2 and BG32 in relation to I. pallida DSM $9630^{\top}$, strains assigned to 'Nostocoida limicola' III and some other representatives of the phylum Planctomycetes. Bootstrap values (from 1000 data resamplings) $>50 \%$ are shown. The 16S rRNA gene sequence of Chlorobium limicola UdG 6040 (GenBank accession no. Y10642) was used as an outgroup (not shown). Bar, 0.1 substitutions per nucleotide position. The same tree topology was obtained with the maximum-likelihood and maximumparsimony methods.

\section{Description of Singulisphaera gen. nov.}

Singulisphaera (Sin.gu.li.sphae'ra. L. adj. singuli single, separate; L. fem. n. sphaera sphere; N.L. fem. n. Singulisphaera a single spherical cell).

Cells are spherical and occur singly, in pairs or in shapeless aggregates. Non-motile. Reproduce by budding. Stalk-like structures are absent. Attach to surfaces by means of amorphous holdfast material. Encapsulated. Colonies are opaque and colourless. Chemo-organotrophic aerobes. Capable of growth under microaerobic conditions. Catalase-, cytochrome oxidase- and urease-positive. Dissimilatory nitrate reduction is negative. Moderately acidophilic and mesophilic. Sensitive to $\mathrm{NaCl}$. The major quinone is MK-6. The major fatty acids are $\mathrm{C}_{16: 0}, \mathrm{C}_{18: 1} \omega 9 \mathrm{c}$ and $\mathrm{C}_{18: 2} \omega 6 c, 12 c$, the last of these being characteristic for the genus. The genus is a member of the phylum Planctomycetes, order Planctomycetales, family
Planctomycetaceae. The type species is Singulisphaera acidiphila.

\section{Description of Singulisphaera acidiphila sp. nov.}

Singulisphaera acidiphila (a.ci.di'phi.la. N.L. n. acidum acid from L. adj. acidus sour; Gr. adj. philos loving; N.L. fem. adj. acidiphila acid-loving).

Has the following characteristics in addition to those given for the genus. Mature cells are 1.6-2.6 $\mu \mathrm{m}$ in diameter. Crateriform pits are scattered over the whole cell surface. Carbon sources $(0.05 \%, \mathrm{w} / \mathrm{v})$ include glucose, fructose, galactose, lactose, cellobiose, maltose, mannose, melibiose, rhamnose, ribose, trehalose, sucrose, xylose, leucrose, $N$ acetylglucosamine and salicin. Ability to utilize fucose, lactate and pyruvate is variable. Unable to utilize raffinose, sorbose, melezitose, glycerol, methanol, ethanol, starch, glucuronic acid, benzoate, caproate, citrate, formate,

Table 4. Major differential characteristics between Singulisphaera gen. nov. and the genus Isosphaera

Data for Isosphaera were taken from Giovannoni et al. (1987a) and Ward et al. (2006).

\begin{tabular}{|lcc|}
\hline Characteristic & Singulisphaera & Isosphaera \\
\hline Arrangement of cells & Single or in pairs & Filaments \\
Colony pigmentation & None & Pink \\
Gliding motility & $-{ }^{*}$ & + \\
Phototaxis & $-{ }^{*}$ & + \\
Respiration & Aerobic or microaerophilic & - \\
Hydrolytic capability & + & - \\
Growth at pH $4.5-5.5$ & + & - \\
Growth at $4{ }^{\circ} \mathrm{C}$ & + & + \\
Growth above $35{ }^{\circ} \mathrm{C}$ & - & + \\
Vitamin requirement & - & - \\
Presence of $\mathrm{C}_{18: 2}$ fatty acids & + & 62 \\
DNA G $+\mathrm{C}$ content $($ mol $\%)$ & $57-60$ & - \\
\hline
\end{tabular}

${ }^{\star}$ Determined under the conditions given by Giovannoni et al. (1987a). 
formaldehyde, fumarate, glutarate, malate, succinate, propionate, mannitol, tartrate, alanine, arginine, asparagine, aspartate, cysteine, cystine, glutamine, glycine, histidine, isoleucine, leucine, lysine, methionine, norleucine, ornithine, phenylalanine, proline, serine, threonine, tryptophan, tyrosine or valine. Capable of hydrolysing laminarin, pectin, chondroitin sulfate, aesculin, gelatin, pullulan, lichenan and xylan. Unable to hydrolyse starch, chitin or cellulose. Shows the following enzyme activities: alkaline and acid phosphatases, esterase, esterase lipase, leucine arylamidase, cystine arylamidase, valine arylamidase, phosphohydrolase, $N$-acetyl- $\beta$-glucosaminidase and $\beta$-galactosidase (API ZYM test). Able to utilize the following nitrogen sources $(0.05 \%, \mathrm{w} / \mathrm{v})$ : ammonia, $\mathrm{N}$ acetylglucosamine, Bacto peptone, Bacto yeast extract, alanine, aspartate, arginine, glutamine, threonine, tryptophan and glycine. Some strains can also utilize asparagine, isoleucine, lysine, phenylalanine, proline and valine. Nitrate and nitrite are not utilized. Vitamins are not required. Resistant to ampicillin, streptomycin, chloramphenicol, lincomycin, kanamycin and novobiocin, but sensitive to neomycin and gentamicin. Capable of growth between $\mathrm{pH} 4.2$ and 7.5 (optimum at $\mathrm{pH}$ 5.0-6.2) and at temperatures between 4 and $33{ }^{\circ} \mathrm{C}$ (optimum at $20-26{ }^{\circ} \mathrm{C}$ ). $\mathrm{NaCl}$ inhibits growth at concentrations above $0.5 \%(\mathrm{w} / \mathrm{v})$. The $\mathrm{G}+\mathrm{C}$ content of the DNA varies between 57.8 and $59.9 \mathrm{~mol} \%$ ( $59.9 \mathrm{~mol} \%$ for the type strain).

The type strain, MOB $10^{\mathrm{T}}\left(=\mathrm{ATCC}\right.$ BAA- $1392^{\mathrm{T}}=\mathrm{VKM}$ B-2454 ${ }^{\mathrm{T}}=$ DSM $18658^{\mathrm{T}}$ ), was isolated from the Sphagnum peat bog Obukhovskoe, Yaroslavl region, northern European Russia. Strains PO2, MPL1015 and BG32, isolated from similar acidic wetlands, are also included in the species.

\section{Acknowledgements}

This research was supported by the Russian Fund of Basic Research (grants no. 06-04-49148 and 07-04-91561), the programme 'Molecular and Cell Biology' of the Russian Academy of Sciences and the Russian Science Support Foundation. We thank A. M. Lysenko for DNA G $+\mathrm{C}$ content analysis, Kees Hordijk and Irene Rijpstra for technical assistance in PLFA and neutral lipid analyses, respectively, and Marc Dumont for critical reading of the manuscript.

\section{References}

Dedysh, S. N., Pankratov, T. A., Belova, S. E., Kulichevskaya, I. S. \& Liesack, W. (2006). Phylogenetic analysis and in situ identification of bacteria community composition in an acidic Sphagnum peat bog. Appl Environ Microbiol 72, 2110-2117.

Felsenstein, J. (1989). PHYLIP - Phylogeny inference package (version 3.2). Cladistics 5, 164-166.

Fuerst, J. A. (1995). The Planctomycetes: emerging models for microbial ecology, evolution and cell biology. Microbiology 141, 1493-1506.

Fuerst, J. A. (2004). Planctomycetes - a phylum of emerging interest for microbial evolution and ecology. WFCC Newsl 38, 1-11.

Fuerst, J. A. (2005). Intracellular compartmentation in planctomycetes. Annu Rev Microbiol 59, 299-328.
Gerhardt, P. (1981). Manual of Methods for General Bacteriology. Washington, DC: American Society for Microbiology.

Giovannoni, S. J., Schabtach, E. \& Castenholz, R. W. (1987a). Isosphaera pallida, gen. nov., and comb. nov., a gliding, budding eubacterium from hot springs. Arch Microbiol 147, 276-284.

Giovannoni, S. J., Godchaux, W., III, Schabtach, E. \& Castenholz, R. W. (1987b). Cell wall and lipid composition of Isosphaera pallida, a budding eubacterium from hot springs. J Bacteriol 169, 2702-2707.

Ivanova, A. O. \& Dedysh, S. N. (2006). High abundance of planctomycetes in anoxic layers of a Sphagnum peat bog. Microbiology (English translation of Mikrobiologiia) 75, 716-719.

Kerger, B. D., Mancuso, C. A., Nichols, P. D., White, D. C., Langworthy, T., Sittig, M., Schlesner, H. \& Hirsch, P. (1988). The budding bacteria, Pirellula and Planctomyces, with atypical 16S rRNA and absence of peptidoglycan, show eubacterial phospholipids and uniquely high proportions of long chain beta-hydroxy fatty acids in the lipopolysaccharide lipid A. Arch Microbiol 149, 255-260.

Kulichevskaya, I. S., Pankratov, T. A. \& Dedysh, S. N. (2006). Detection of representatives of the Planctomycetes in Sphagnum peat bogs by molecular and cultivation approaches. Microbiology (English translation of Mikrobiologiia) 75, 329-335.

Kulichevskaya, I. S., Ivanova, A. O., Belova, S. E., Baulina, O. I., Bodelier, P. L. E., Rijpstra, W. I. C., Sinninghe Damstè, J. S., Zavarzin, G. A. \& Dedysh, S. N. (2007). Schlesneria paludicola gen. nov., sp. nov., the first acidophilic member of the order Planctomycetales, from Sphagnum-dominated boreal wetlands. Int J Syst Evol Microbiol 57, 2680-2687.

Lindsay, M. R., Webb, R. I., Strous, M., Jetten, M. S., Butler, M. K., Forde, R. J. \& Fuerst, J. A. (2001). Cell compartmentalization in Planctomycetes: novel types of structural organization for the bacterial cell. Arch Microbiol 175, 413-429.

Liu, J.-R., McKenzie, C. A., Seviour, E. M., Webb, R. I., Blackall, L. L., Saint, C. P. \& Seviour, R. J. (2001). Phylogeny of the filamentous bacterium 'Nostocoida limicola' III from activated sludge. Int J Syst Evol Microbiol 51, 195-202.

Ludwig, W., Strunk, O., Westram, R., Richter, L., Meier, H., Yadhukumar, Buchner, A., Lai, T., Steppi, S. \& other authors (2004). ARB: a software environment for sequence data. Nucleic Acids Res 32, 1363-1371.

Marmur, J. (1961). A procedure for the isolation of deoxyribonucleic acid from microorganisms. J Mol Biol 3, 208-218.

Neef, A., Amann, R., Schlesner, H. \& Schleifer, K.-H. (1998). Monitoring a widespread bacterial group: in situ detection of planctomycetes with 16S rRNA-targeted probes. Microbiology 144, 3257-3266.

Nichols, D. S., Nichols, P. D. \& McMeekin, T. A. (1995). A new n-C$31 / 9$ polyene hydrocarbon from Antarctic bacteria. FEMS Microbiol Lett 125, 281-285.

Owen, R. J., Lapage, S. P. \& Hill, L. R. (1969). Determination of base composition from melting profiles in dilute buffers. Biopolymers 7 , 503-516.

Reynolds, E. S. (1963). The use of lead citrate at high $\mathrm{pH}$ as an electron-opaque stain in electron microscopy. J Cell Biol 17, 208-212.

Schlesner, H. (1994). The development of media suitable for the microorganisms morphologically resembling Planctomyces spp., Pirellula spp., and other Planctomycetales from various aquatic habitats using dilute media. Syst Appl Microbiol 17, 135-145.

Sinninghe Damsté, J. S., Rijpstra, W. I. C., Schouten, S., Fuerst, J. A., Jetten, M. S. M. \& Strous, M. (2004). The occurrence of hopanoids in planctomycetes: implications for the sedimentary biomarker record. Org Geochem 35, 561-566. 
Sittig, M. \& Schlesner, H. (1993). Chemotaxonomic investigation of various prosthecate and/or budding bacteria. Syst Appl Microbiol 16, 92-103.

Staley, J. T., Fuerst, J. A., Giovannoni, S. \& Schlesner, H. (1992). The order Planctomycetales and the genera Planctomyces, Pirellula, Gemmata and Isosphaera. In The Prokaryotes: a Handbook on the Biology of Bacteria: Ecophysiology, Isolation, Identification, Applications, 2nd edn, pp. 3710-3731. Edited by A. Balows, $\mathrm{H}$. Trüper, M. Dworkin, W. Harder \& K. H. Schleifer. New York: Springer.

Wang, J., Jenkins, C., Webb, R. I. \& Fuerst, J. A. (2002). Isolation of Gemmata-like and Isosphaera-like planctomycete bacteria from soil and freshwater. Appl Environ Microbiol 68, 417-422.
Ward, N., Rainey, F. A., Stackebrandt, E. \& Schlesner, H. (1995). Unraveling the extent of diversity within the order Planctomycetales. Appl Environ Microbiol 61, 2270-2275.

Ward, N., Staley, J. T., Fuerst, J. A., Giovannoni, S., Schlesner, H. \& Stackebrandt, E. (2006). The order Planctomycetales, including the genera Planctomyces, Pirellula, Gemmata and Isosphaera and the Candidatus genera Brocadia, Kuenenia and Scalindua. In The Prokaryotes: a Handbook on the Biology of Bacteria, 3rd edn, vol. 7, pp. 757-793. Edited by M. Dworkin, S. Falkow, E. Rosenberg, K. H. Schleifer \& E. Stackebrandt. New York: Springer.

Weisburg, W. G., Barns, S. M., Pelletier, D. A. \& Lane, D. J. (1991). $16 \mathrm{~S}$ ribosomal DNA amplification for phylogenetic study. J Bacteriol 173, 697-703. 